\title{
IS FOREIGN EXCHANGE INTERVENTION EFFECTIVE?: THE JAPANESE EXPERIENCES IN THE 1990S
}

\author{
Takatoshi Ito \\ Working Paper 8914 \\ http://www.nber.org/papers/w8914 \\ NATIONAL BUREAU OF ECONOMIC RESEARCH \\ 1050 Massachusetts Avenue \\ Cambridge, MA 02138 \\ April 2002
}

An earlier version of this paper was written for and presented at the the Goodhart Festschrift conference, held at the Bank of England on 15-16 November 2001. Comments by Marcus Miller and other participants in the conference were quite helpful. Later versions were presented at Victoria University in Wellington and the Reserve Bank of New Zealand. The author benefited from comments and discussions with Peter Kenen, Christie Smith, and Kelly Eckhold. The author gratefully acknowledges research assistance by Tomoyoshi Yabu. All the data used in this paper are publicly available. The views expressed herein are those of the author and not necessarily those of the National Bureau of Economic Research.

(C) 2002 by Takatoshi Ito. All rights reserved. Short sections of text, not to exceed two paragraphs, may be quoted without explicit permission provided that full credit, including (C) notice, is given to the source. 
Is Foreign Exchange Intervention Effective?:

The Japanese Experiences in the 1990s

Takatoshi Ito

NBER Working Paper No. 8914

April 2002

JEL No. F31, E58, G15

\begin{abstract}
This paper examines Japanese foreign exchanges interventions from April 1991 to March 2001 based on newly disclosed official data. All the yen-selling (dollar-purchasing) interventions were carried out when the yen/dollar rate was below 125, while all the yen-purchasing (dollar-selling) interventions were carried out when the yen/dollar was above 125 . The Japanese monetary authorities, by buying the dollar low and selling it high, have produced large profits, in terms of realized capital gains, unrealized capital gains, and carrying (interest rate differential) profits, from interventions during the ten years. Profits amounted to 9 trillion yen ( $2 \%$ of GDP) in 10 years. Interventions are found to be effective in the second half of the 1990s, when daily yen/dollar exchange rate changes were regressed on various factors including interventions. The US interventions in the 1990s were always accompanied by the Japanese interventions. The joint interventions were found to be 20-50 times more effective than the Japanese unilateral interventions. Japanese interventions were found to be prompted by rapid changes in the yen/dollar rate and the deviation from the long-run mean (say, 125 yen). The interventions in the second half were less predictable than the first half.
\end{abstract}

Takatoshi Ito

Research Center for Advanced Science and Technology University of Tokyo

and NBER

itointokyo@aol.com 


\section{$\underline{\text { 1. Introduction }}$}

Foreign Exchange Interventions have been one of the most secretive activities of monetary authorities around the world. They have been always a source of controversy, both in the academic literature and in practice. Some have believed that intervention cannot be effective based on a popular monetary model of determining the exchange rate, and also argued that the size of intervention tends to be overwhelmed by the market size, especially for major currencies. Others have argued that in some instances, interventions seemed to be effective by changing the sentiment of the market through signaling policy intentions. Some models, they also argue, that take into account the risk difference between domestic and foreign bonds would show some influences of intervention through portfolio shifts among the private sector. A dominant view on effectiveness of intervention has changed the side a few times in the past decades. The monetary authorities tended to intervene heavily in the foreign exchange market during the transition from the Bretton Woods system, that collapsed in August 1971 to the floating of major currencies in the beginning of 1973. Even after the floating began, some monetary authorities in among large economies were believed to be intervening heavily in the foreign exchange market.

In the early 1980s, the Jurgensen study (Jurgensen (1983) and also Edison (1993)), which benefited from obtaining data from the participating authorities as a part of official-sector study, concluded that interventions, especially sterilized interventions, did not have much impact on the exchange rate. ${ }^{1}$ Nonsterilized interventions have some effects, but only temporarily. However, apparent success of concerted interventions following the Plaza Accord of September 1985 in driving down the overvalued US dollar renewed academic interest. A series of papers by Dominguez and Frankel showed some effects of interventions on the level, volatility, and risk premium of exchange rates. (See Dominguez(1990), Dominguez and Frankel (1993a, b, c)). They have emphasized the 
signaling effect of intervention that would work on expectation of institutional investors. Although effects of interventions have been debated extensively, no conclusive consensus has emerged. (See Sarno and Taylor (2001) for a most recent survey, and Ramana and Samiei (2000) for the work on the effectiveness of intervention on the yen-dollar exchange rate before the data disclosure.)

Except for the United States, intervention data have not been disclosed publicly among the G7 countries. Although the authorities could exchange information for internal studies on intervention through G10 or BIS, outside researchers could not obtain intervention data freely. In some cases, data were released to selected researchers for academic purposes only, with condition that data would be destroyed after the research was concluded. Empirical studies of intervention have become a popular exercise as data on intervention have become available to researchers. The past empirical studies have mixed results on the effectiveness of foreign exchange interventions.

The Japanese authorities had not released intervention data to non-officials, even for academic research, although reported data to international organizations were occasionally used for internal studies among official circles, including Group of 10 (G10) and the Bank of International Settlements (BIS). Some researchers in the academic and private sector had to go to newspaper or wire service to create proxies (mostly zero-one dummy variables) for Japanese interventions.

In July 2001, the Japanese Ministry of Finance disclosed daily intervention records from April 1991 to March 2001. The intervention record in the future will be disclosed in the same format four times a year. (MOF home page: www.mof.go.jp/english/e1c021.htm).

The rest of this paper is organized as follows. Section 2 will describe some institutional details of intervention operations in Japan. Section 3 will describe the yen-dollar rate movement and intervention phases in the 1990s. Section 4 estimates profits/losses from intervention operations. Realized gains/losses from buying and selling the US dollars, the carrying profits/losses of large foreign reserves, and unrealized gains/losses at the end of sample period are estimated. Section 5 
discusses the intervention strategy and intention. In Section 6, regression results are presented to show that Japanese interventions tended to be successful at least in the short run, for the second half of the decade. Section 7 examines a reaction function, a regression to explore factors that prompt the authorities to intervene. Section 8 concludes the paper.

\section{$\underline{\text { 2. Data description and Institutional details }}$}

In August 2000, the Japanese Ministry of Finance started to disclose data of daily intervention in the preceding quarters (that is, the delay in disclore by one to four months). The historical data, from April 1991 to March 2000, was released in July 2001. Interventions in the future will be also disclosed in the same format, four times a year. What exactly are disclosed and what are not can be summarized as follows. The disclosed data by the Japanese Ministry of Finance include the following information: (a) the date of intervention, (b) the yen amount and direction (sold/bought) of intervention for the day, (c) currencies that are involved in intervention. What is not disclosed, but would have been desired by researchers, are the following: (a) Exact time of the day (hour, minute, second) and how many times within the day; (b) market (Tokyo, London, or New York) where the intervention was carried out; (c) the exact exchange rate that intervention was carried out. ${ }^{2}$ Although it was never mentioned explicitly, it is understood that all interventions were carried out in the spot market, and no forward market intervention or interventions using derivative market has been used. Since the exact exchange rate that are applicable to a particular intervention transaction is not disclosed, the central rate of the Tokyo market of the day of intervention will be used in this study to convert the yen-amount of an intervention to the dollar-amount of the intervention. Since the central rate is the rate at which most transactions took place for the day, it can be regarded as a good proxy for the intervention exchange rate.

The Japanese intervention has been under the jurisdiction of the Ministry of Finance. An 
intervention decision — not every detail, but broad decision — has to be approved by the Minister. Detailed strategies have been formulated in the line of bureaucratic hierarchy from the Vice Minister for International Finance, the Director General of the International Finance Bureau, and the Director of Foreign Exchange and Money Market Division, that is the division in charge of intervention and foreign reserves. ${ }^{3}$ Movements and conditions in the foreign exchange market are constantly monitored by the Division in close consultation with the Bank of Japan. Intervention orders, when issued, are carried out by the Bank of Japan.

Financial bills (short-term government bills, with maturity of three months) are issued to the market to obtain yen cash that are used to purchase the foreign currency denominated assets in the intervention. Since domestic bills are issued to obtain the yen before the dollar is purchased through intervention by the yen, the intervention can be regarded as automatically sterilized. ${ }^{4}$ Financial bills are rolled over, when foreign currency denominated assets are maintained as foreign reserves. Sales of the foreign currency denominated assets result in reducing outstanding financial bills by redeeming them upon maturity. The balance sheet of the Special Accounts of the Foreign Exchange Fund discloses these assets and liabilities. Strictly speaking, foreign reserves are not on the balance sheet of the Bank of Japan, but as a part of budgetary operations. Some of the profits from the Special Accounts are transferred to the general budget. The Japanese foreign reserves can be regarded as a huge investment fund managed by the Ministry of Finance. However, details of asset and liability of the Account, such as composition of foreign currency assets by currency or by maturity is not disclosed. At the end of March 1999, the Special Account lists about 32 trillion yen of foreign currency denominated securities and deposits.

The disclosure practice of foreign exchange market intervention varies from country to country. The monetary authorities of the United States are most transparent. The decision of intervention is jointly made by the Treasury and the Federal Reserve Board, and carried out by the 
Federal Reserve Bank of New York (NY Fed), with a lead by the Treasury. The data of intervention, disclosed publicly from NY Fed, includes amounts, day and time of intervention. The data go back to the 1970s. The Bundesbank and other euro-zone central banks did not disclose the intervention data publicly, but some data were released for academic research. After the euro was launched, decisions on intervention are transferred to the European Central Bank (ECB), with consultation with the EcoFin council. The ECB has not disclosed intervention data. Although the monetary authorities of the United Kingdom, the H.M. Treasury, and the Bank of England, started to disclose intervention data in 2000 , no historical data have been disclosed publicly. Table 1 summarizes the disclosure practice among the major monetary authorities.

\section{Insert Table 1 about here}

The disclosed amount of Japanese intervention on day $t$ could reflect intervention in the Tokyo market of day t, intervention in the European and/or U.S. time zones of day $\mathrm{t}$ (in local time), either carried out directly by the Bank of Japan or carried out by other central banks on behalf of the Bank of Japan. With the disclosure constraint of daily aggregation, the best proxy for the exchange rate just before the intervention on day $t$ is the New York close of day (t-1), and the proxy for the exchange rate just after the intervention is the New York close of day t. Although most of the U.S. interventions are conducted in the New York market (Humpage (1999)), they could be theoretically carried out in other markets. Timeline for possible patterns of intervention within a day is shown in Table 2.

\section{Insert Table 2 about here}

\section{Movements of the yen/dollar exchange rate in the 1990s}

Movements of the yen/dollar exchange rate and intervention points are reviewed in this section in order to give an overall picture of the decade. Some accounts of interventions may be provided in details. However, a blow-by-blow account of interventions during the period of 
spectacular yen appreciation to 80 yen/dollar and turn back to 100 yen/dollar in 1995 will be important in designing a more formal analysis later.

Figure 1 shows the daily movements of the exchange rate (upper panel) and accumulated monthly interventions on the corresponding time scale (lower panel) for the period from April 1991 to March 2001. From the figure, it can be seen that the yen has fluctuated between 80 yen/dollar and 146 yen/dollar during the ten year period. The yen has appreciated from near 140 yen/dollar in the spring of 1991 to 80 yen/dollar in April of 1995, then it turned around and depreciated to 146 in the summer of 1998. The yen/dollar rate then went from 146 to near 100 in the next two years. The yen depreciated back to 125 by the end of the sample period.

\section{Insert Figure 1}

Interventions have been conducted time to time, as the yen becomes weaker or stronger than the ten-year average. When the yen/dollar rate was near 140 yen/dollar in May-June, 1991, there were three days of interventions to sell the dollar (and buy the yen). The lowest (in terms of dollar value in yen) point of intervention was 139.20 and the highest point of intervention was 141.80 . This round of intervention appears to coincide with the turnaround of the yen, because the highest intervention rate coincides with the highest in this period.

There was another round of interventions in support of the yen from January 1992 to August 1992. There were 23 days of interventions during the eight months. Interventions appear to have been carried out to prevent the yen from becoming too weak again, or losing the gains made in the second half of 1991. Interventions were conducted in a range between 126.50 and 134.50. The intervention started when the yen was at around 128. The first intervention of this round was quite successful in sending the yen value stronger (at around 125). However, after a month, the yen became weaker and hovered around 130. Several interventions from February to April 1992 did not stop the yen from 
depreciating to 134 . The yen depreciation trend was finally turned around at 134.75. Even after the yen started to strengthen, interventions continued to push the value of the yen so that the yen appreciation continues. Interventions were in small lots, typically below 50 billion yen in a day, and carried out sometimes infrequently and sometimes in almost everyday. Interventions continued until the yen reached below 128. Therefore, this round of intervention can be viewed to be such interventions that were aimed at preventing the yen from weakening beyond 135, and that further pushed the yen to appreciate toward the 127 level.

The direction of interventions changed in April 1993. By then, the yen was considered to have appreciated too much. The intervention in support of the US dollar started, when the yen appreciated beyond the 115 yen/dollar level on April 2, 1993. The neutral zone - the yen band between the last yen-buying intervention and the first yen-selling intervention - turned out to be about 14 yen.

Interventions of this episode continued until the yen peaked at 100.50 yen/dollar on August 17, when the Japanese monetary authorities sold more than 200 billion yen in a day. During the months from April to August 1993, the yen appreciated despite interventions to sell the yen. In that sense, it appeared that numerous interventions during the five-month period were not particularly effective. On the other hand, if one interprets that if those interventions were conducted to smooth the yen appreciation process, or to prevent an eventual defense line of 100 , then the interventions from April to August may be considered to be successful. Moreover, when exchange rate dynamics around intervention days are examined closely, a tendency is detected that interventions are prompted by a sudden yen appreciation (say, by 2 yen in the preceding day; e.g. April 2, April 19, May 26, and June 28), and that interventions stopped the yen from depreciating for only a day or so. However, an assessment may be different if the long-term effect of interventions are considered. One may conclude that lean-against-the-wind operations from April to August were a failure in that the yen appreciated 
by 15 yen in the five-month period, despite repeated interventions. On the other hand, it was a success, in that each intervention tended to stop yen appreciation in the short-run, so that the appreciation was "smoothed". It was also regarded as a success in that the yen appreciation was stopped short of a psychological barrier of 100, because of repeated interventions. Evaluations of intervention effects vary depending on what was the intent of interventions, which is not observable.

Even after the yen momentum was turned around on August 17 at just before the 100 level, intervention continued until the yen reached 104.5 on September 7. In broader sense, the intervention from August to September was to lean in the wind. Interventions were not employed between September 7, 1993 and February 15, 1994, when the yen fluctuated between 105 and 113 yen/dollar.

The intervention of February 15, 1994 seems to be prompted by a sudden appreciation of the yen overnight (by 2 yen) to 102 . From this point on, the monetary authorities intervened at least several days in one month and in total 55 days in the ten-month period, from February to November, in the range of $96.45-105.10$. It is hard to say whether the objective of intervention was to keep the yen from appreciating beyond 100 (in that case, it failed in late June 1994) or to make the yen appreciation smoother than otherwise.

Heavy interventions were conducted from late June to the mid-July 1994, when the yen/dollar rate approached the level 100, again. The joint intervention kept the yen from appreciating beyond the 100 barrier only for a few days. During a period from June 20 to July 1, yen-selling interventions were conducted for 11 days with total of 538 billion yen. On June 24, 136 billion yen of the Japanese monetary authorities, combined with the US intervention of 610 million dollar worth of yen, were sold with an apparent intention to prevent the yen from appreciating beyond 100 . The yen-dollar rate for the first time in its post-war history, broke into the double-digit number on June 27.

After the July 11-12 intervention, the yen-dollar rate moved back above the 100 level. In the mid-August, the yen/dollar rate broke again the 100 level. Interventions were conducted for six days in 
a row in an attempt to stop appreciation. These interventions were barely successful in bringing the rate back above 100. The interventions in September also made little impact on the level of the yen. The yen appreciated from mid-August to the beginning of November, despite 19 interventions, and reached 96.45 yen/dollar on November 3. On November 2, Japanese intervention sold more than 100 billion yen, and the US intervention sold 800 million dollars worth of the yen, followed by another joint interventions - the Japanese selling 50 billion yen and the U.S. 500 million dollars worth—on November 3 . These two days of joint interventions finally turned around the yen. The yen hovered just at 100 at the end of 1994 . There were no lean-in-the-wind interventions to sell the yen trying to chase the yen away from the 100 level. During 1994, interventions were conducted in 55 days, selling a total of 2.639 tillion yen.

No intervention was conducted from November 3, 1994 to February 17, 1995. To the first intervention in 1995 was conducted on February 17, when the yen/dollar rate was at around 97. During the period from February 17 to April 18, intervention was conducted in 34 days, with a total amount of 2.3 trillion yen, in support of the U.S. dollar. However, the yen gradually appreciated despite these interventions. During the month of March 1995, a battle was especially fierce, with the market pressuring the yen to appreciate beyond the 90 mark, while the authorities defending the 90 yen mark. In March, the Japanese monetary authorities intervened on 21 days out of 23 business days. The U.S.-Japan joint intervention was conducted both on March 2 and 3. However, the yen steadily appreciated in these two days, to the level of 95 yen/dollar. On March 6, the yen/dollar rate became 93, and on March 13, just above 90. From March 13 to 31, Japanese intervention was conducted everyday for three weeks, with a total amount of 1.3 trillion yen. The yen/dollar rate stayed in a narrow range of 88-90 yen, although the amount of intervention varied widely from a day to next. It looked like the case that the intervention was conducted to keep the yen from appreciating beyond 88 yen per dollar. However, there was no resolve on the part of the authorities to push the yen back above the 90 level. 
Since the yen appreciated gradually despite the interventions, it would be difficult to argue that interventions were successful.

On April 3 and 4, there were joint interventions by the Japanese and US authorities, again. (On April 3, the Japanese monetary authorities sold 120 billion yen, and the US 750 million dollars worth of yen; and on April 4, the Japanese 43 billion yen and the US 250 million dollars worth.) Despite this show of force, the yen did not depreciate, but stuck at 86 yen/dollar. The yen started to appreciate further sfrom the following day. On April 10, the yen/dollar rate became 83 yen/doolar, and on April 18, it became 81, despite repeated unilateral interventions by the Japanese authorities (on April $6,7,10,14,17$, and 18). The yen recorded the all-time high of 79.75 , for a few seconds, or 80.25 as the Tokyo close on April 19. Incidentally, there was no intervention that day.

During the swift yen appreciation from 88 on April 3 to 80 yen/dollar on April 18, the Japanese authorities sold 500 billion yen, which was less than half of what was sold in the March intervention in an apparent attempt to defend 90 . The very swift move of the yen in the first half of April may be puzzling. It was said that technical factors such as knock-out options and delta hedge strategies were responsible for the movement. Many, if not all, economists regarded the level of 80 yen/dollar, or movement from 100 to 80 in three and half months, out of sync from fundamentals at the time. Trade conflicts over the auto talks between Japan and the United States were frequently blamed for the swift yen appreciation at this time. The market believed that the US Trade Representative wanted to put pressure on Japan by creating the yen appreciation.

In mid-April, the yen turned around, but did not depreciate significantly in the following months. By mid May, the yen depreciated to the level of 87 yen per dollar. However, toward the end of May, the yen appreciated again. On May 30, the yen/dollar rate reached the level of 82. On May 31, the joint intervention by the Japanese and US monetary authorities was conducted, and that brought the yen/dollar rate to 84.5 . 
The Japanese intervention was conducted on June 28 , at the level of 84 yen/dollar. This was the first intervention conducted by new Director General of International Finance Bureau, Dr. Sakakibara. The second intervention by Dr. Sakakibara was on July 7, joint with the U.S. authorities, which depreciated the yen by about 2 yen, to 86.8 yen/dollar at the New York close. (The intervention amount was not particularly large. The Japanese sold 580 billion yen, and the U.S. sold 330 million dollar worth of yen.)

Toward the end of July, the yen depreciated to the 88 yen/dollar level. On August 2, a large-scale joint interventions were carried out. The Japanese authorities sold 676 billion yen, and the US authorities sold 500 million dollars worth of the yen. The joint intervention on August 2 was accompanied by policy measures, for example to liberalize the restriction of pension funds investment abroad. The joint intervention had effects to cause yen depreciation by 3 yen, and the yen/dollar level restored the 90s level, for the first time in four and half months. Sakakibara recalls the day: "We intervened aggressively in Tokyo. The yen/dollar rate started at 87 in the Tokyo market, but finished at around 90 due to our intervention to push up the level by the close. Later in the day, the concerted intervention was carried out in New York. Intervention amounts were highest in history...After the Tokyo market close and before the New York market open, Minister Takemura phoned Secretary Rubin and reported the market condition in Tokyo, and consulted on intervention [strategy] in New York. I was glad that Secretary Rubin regarded highly of the [Japanese policy] measures announced and interventions carried out in Tokyo...And, concerted interventions in New York finally broke the level of 90." (Sakakibara (2000), p. 124)

Additional interventions were carried out on August 11 (Japanese unilateral) and on August 15 (Japan-US-Germany, joint). These interventions were quite effective, and the yen reached the 97 yen/dollar. These interventions were of the lean-in-the-wind type.

In September, final pushes to restore the level of 100 was attempted. On September 6, the 
Japanese authorities intervened with 226 billion yen, to bring the yen to 98.9 by the New York close. On September 8, a record high of 858 billion yen was sold by the Japanese authorities to break the 100 level. Sakakibara recalls the moment as follows: "In the afternoon of the $8^{\text {th }}$ [of September], we bought dollars more and more, but the yen/dollar rate did not move at the level just below 100, for 30 minutes to one hour. ... In the end, we used electronic broking. At last, the yen/dollar rate went over the 100 , and posted 100.20 on the screen. Cheers broke out in the dealing room of the Ministry" (Sakakibara (2000), p.129)

Interventions under Sakakibara's direction, those between June 28 and September 22, have distinctive features, that should be contrasted to the previous interventions. First, these interventions were not prompted by sudden yen depreciation of the preceding day or two. They seemed to be motivated by dissatisfaction with the prevailing yen/dollar level. The intervention was conducted to change actively the level of the yen/dollar rate, while the previous interventions were conducted in an attempt to defend a certain level or smooth the change. In short, the previous interventions were a lean-against-the-wind type, while the Sakakibara interventions were a lean-in-the-wind type. Second, the frequency of intervention was less than before, but the per-day amount of intervention was larger than before. Dr. Sakakibara himself noted the difference, emphasizing that it was a deliberate choice. Talking of interventions by his predecessor, he writes "The market was accustomed to interventions, because they were too frequent. The interventions were taken as given. Most interventions, including joint interventions, were predictable, so that interventions, even joint ones, had only small, short-term effects, and could not change the sentiment of the market." (Sakakibara (2000), p.119) "[T]he change in intervention philosophy and technique [was introduced]. For this, all I have to do was to make a decision and convince the Vice Minister and the Minister of [its desirability]. For one, the frequency of interventions was reduced substantially, and per-intervention amount was increased, in order to push up the level [of the dollar vis-à-vis the yen]" (ibid., p.120) 
One more intervention was conducted on September 22. That seemed to have been prompted by a sudden yen appreciation unlike previous Sakakibara interventions. In the first half of 1995, before June 21, interventions were conducted in 35 days with selling 2,359 billion yen, while in the second half of 1996, after June 21, interventions were conducted only in 8 days with selling 2,000 billion yen.

After September 1995, the yen/dollar rate stayed at around 100 for the rest of the year, and then depreciated, without interventions, to the 107 level by February 1996. When the yen appreciated back toward 104, a series of interventions was conducted. However, five days of interventions in the last ten days of February did not produce any measurable impact on the rate. It was quite unlike Sakakibara interventions of 1995 , in that this time it seemed to be prompted by yen appreciation just before intervention, and despite interventions, the yen/dollar rate did not move. Sakakibara claims that for these interventions, he detected that yen appreciation pressures had been building up, and absorbing those pressures by interventions were important to prevent potential yen appreciation. Therefore, even though the yen did not depreciate despite a total of 1,603 billion yen interventions, he would still claim a success. (See Sakakibara (2000), p. 138)

This kind of detailed information is quite important in designing the empirical analysis. First, interventions by Sakakibara may be different from others in how it was prompted by the market movement and how effective they were in influencing the yen/dollar rate. Therefore the reaction function and a regression to measure effectiveness may have a structural break at the Sakakibara's assumption of the Director General post. Second, how to judge effectiveness of interventions is difficult, because intentions of interventions vary from a person in charge to another, or a depreciation phase from an appreciation phase.

Intervention did not take place from February 1996 to the end of 1997, as the yen steadily depreciated. When the yen depreciated over the level of 130, interventions in support of the yen, was 
carried out in December 1997. It was five and half years since the last yen-buying intervention was carried out, and almost two years had passed since the last intervention with an opposite direction. The last yen-selling intervention point was 105.70 (Tokyo central rate), and the rate at which yen was bought this time was 127.00 yen. This implies that the neutral band-the difference between the yen-selling intervention point and the yen-buying intervention point—was more than 21 yen. Three days of interventions did not cause yen appreciation. In fact, the yen gradually depreciated to 129 during the three days of interventions that are intended to appreciate the yen. The yen depreciated to the 130 level in January 1998. When the yen depreciated to 135 and then appreciated back to 132 in April, the heavy intervention was conducted. The Japanese monetary authorities conducted interventions on April 9, 10 buying a total of 2.8 trillion yen, a record amount in the 1990s. However, this pushed down the dollar only by 1 to 2 yen/dollar. It might not be a failure, but not a great success considering the large size of intervention.

The yen depreciated to 137 in May, and to the 140s in early June without being challenged by interventions. When the yen depreciated to 143 on June 15, a joint intervention was pulled off, and quickly brought the yen to the level of 136 (a jump of 7 yen) on June 16 . The yen stayed at around 140 until August, when the yen depreciated back to upper 140s range, again. However, no intervention was conducted. The yen gradually appreciated in September, and then appreciated sharply by 10 yen on October 7, to 120 yen/dollar, without intervention. This is considered to be a result of hedge funds unwinding yen-carry trade positions. ${ }^{5}$

It is remarkable that only a small number of interventions was conducted in 1997 and 1998, although the yen/dollar rate widely fluctuated. A large part of fluctuations might reflect worsening conditions of Japanese financial institutions. Two large financial institutions failed in November 1997, and another large financial institution was failing in 1998. The systemic vulnerability invited selling and short-selling of Japanese assets and currency during the summer of 1998. The low interest rate and 
depreciating yen attracted large hedge funds and other financial institutions to borrow in yen-yen carry trades.

The yen suddenly appreciated in October, as explained before, and continued to appreciate and reached 110 yen/dollar by the end of the year. The direction of intervention switched again in 1999. On January 12, the Japanese authorities sold the yen and had an effect of depreciating the yen from 109 yen/dollar on the previous day to 112 yen/dollar. This intervention seemed to be quite effective. The yen trend was reversed, and the yen depreciated toward 123 yen/dollar in May 1999. The yen started to appreciate again in June 1999.

This time, the authorities seemed to be less tolerant on appreciation compared to the January intervention at around 110. In June, four interventions were conducted, pushing the yen from 118 to 122, with selling of 2.9 trillion yen. Despite the large size of interventions, the degree of yen depreciation was modest. This may be due to a relatively high yen/dollar level to conduct yen-selling interventions. Not very many market participants were considered that the yen would depreciate further into the high $120 \mathrm{~s}$.

The yen gradually appreciated from the 120 level in July 1999 to the 102 by the end of the year, despite 9 interventions, selling 3.9 trillion yen. On January 3, 2000, the yen reached 101 yen/dollar, threatening the critical 100 level. The intervention of January 4 depreciated the yen to 103 , and set the trend of subsequent depreciation. There were three more interventions in March and April, to make sure the yen depreciation trend to stay. The yen depreciated to 126 yen/dollar by March 2001, the end of this sample period.

From the quick review of yen fluctuations and intervention in the 1990s, several observations, that can be helpful in designing a more formal analysis, can be drawn. First, interventions styles - frequency, per-intervention amount, and predictability from the market—were different before and after June 1995. The change in style was a deliberate choice of Director General 
Sakakibara who assumed the office in June 1995. Second, the period of Great yen appreciation in the first half of 1995, from 100 to 80 yen/dollar, despite repeated, numerous interventions seemed to be a very extraordinary period. Third, looking at the ten-year period as a whole, the dollars were bought (the yen was sold) when the dollar was cheap (the yen appreciated), and the dollar was sold when the dollar was expensive. The middle point in switching the direction of intervention was at around 125 yen/dollar. Fourth, in many, but not all, occasions, an intervention seemed to be prompted by a sharp move of the yen/dollar rate in the preceding day. However, some interventions were conducted without a sharp changes, especially the early ones by Sakakibara. Fifth, in some cases interventions worked in the sense that the yen moved (within a day) in the intended direction, but in some cases there were no measurable movement (within a day). Sixth, evaluations of effects of intervention are much more difficult in the medium term effect (over several days or longer).

\section{Were interventions profitable?}

As noted in Section 3, all of the dollar-purchasing (yen-selling) interventions were conducted below the 125 level, while all of the dollar-selling (yen-purchasing) interventions were conducted above the 125 level. Table 3 shows the buying and selling operations aggregated in the 5-yen brackets.

\section{Insert Table 3 about here}

In the sense, the Japanese authorities bought the dollar low and sold high. This indicates that the Japanese monetary authorities are a profitable fund manager, implying that they are a "stabilizing speculator", in the sense of Milton Friedman. In broader sense, the fluctuations of the yen/dollar rate would have been more than the reality, had the interventions not been conducted.

In this section, profits earned by the Japanese authorities are estimated. Profits from interventions can be categorized in three factors: (1) Realized capital gains, that is, profits/losses 
realized by buying and selling US dollars; (2) Realized carry costs, that is, profits/losses resulting from the difference between interest costs of maintaining the (accumulated) yen liability and interest income from holding the (accumulated) dollar assets, summed up over ten years; and (3) Unrealized capital gains, that is the difference between the mark-to-market value of the (accumulated) dollar asset at end March 2001 compared to the average cost of those assets.

First, let us calculate the capital gains and the average inventory costs. The dollar-purchasing (yen-selling) interventions amounted to 21,186.1 billion yen, with purchasing values of 203.4 billion dollars, when the daily intervention amount in the yen was converted to the dollar equivalent at the central rate of the Tokyo market. The dollar-selling (yen-purchasing) interventions amounted to $4,879.3$ billion yen, with selling values of 37.4 billion dollars. Over the ten-year period, the average yen/dollar rate for the dollar-selling intervention was 130.38 yen (4879.3/37.4), and the average yen/dollar rate for the dollar-purchasing intervention was 104.17 yen (21186.1/203.4). Therefore, the realized capital gains are estimated as 981 billion yen (=37.4 billion dollars x (130.38-104.17)).

Subtracting the 37.4 billion dollars that are sold from the 4,879.3 billion dollars that were bought, the inventory (foreign reserves from the 1990s interventions) at the end of sample period can be estimated. This amounts to 4,841.9 billion yen, disregarding interest earning and costs of maintaining the position, that are calculated separately. The difference between the mark-to-market as of March 30, 2001 (New York close), that is 126.25 yen, and the average inventory cost, 104.17, is the unit profit per dollar. This amounts to 3,665.2 billion yen. These calculations are shown in Table 4.

\section{Insert Table 4 about here}

What is more difficult is to estimate the interest profits/losses. What is clear is that the Japanese authorities made profits on this department too, because for most of the 1990s, the Japanese interest rate was much lower than the U.S. interest rate. Details of the calculation are shown in Table 5. 
We assume that on every quarter, the 3-month interest rate of government securities (Financial Bills) are paid out to the balance of accumulated intervention in yen, while the 3-month interest rate of the US Treasury bills were earned on the balance of accumulated dollar denominated assets are earned. With this approximation, the interest profit is estimated as 3,975 billion yen. This is probably an underestimate as it assumes that the profits from the interest differentials are paid out to the general account from the special account (recall Section 2), in other words, compounding of interest incomes is disregarded.

\section{Insert Table 5 about here}

To recap, the Japanese authorities are estimated to have earned (1) Realized gains of 981 billion yen; (2) interest profits of 3,975 billion yen; and (3) unrealized gains of 3,665 billion yen. A rough estimate of 8.6 trillion yen was earned during the ten years. So, indeed the interventions were hugely profitable.

In the above analysis, profits/costs of the position created by interventions prior to April 1, 1991, and passed on to the persons in charge as of April 1, 1991, are not considered. Interventions prior to April 1, 1991 resulted in certain sizes of the dollar asset and the yen liability in the foreign exchange account as of March 31, 1991. Profits and losses from holding the position are not considered in the paper. Since the size of the interventions after April 1991 dwarfs the presumed size of interventions in the 1980s, taking into account the profits/losses of the March 1991 positions being carried over or liquidated in the following ten years would be minor compared to the profits/losses of the 1990s interventions. In a first approximation, the position at the end of March 31, 1991 can be regarded to have been carried over for ten years. Carrying profits of the position would reflect the calculated carry profits of the 1990s, namely generating large profits, from higher dollar interest rates during most of the 1990s. On the other hand, the unrealized gains/losses of the position as of March 31, 1991 mark-to-market in March 31, 2001 are negative, since the yen/dollar rate on March 31, 1991 was 
139.10 and the yen/dollar rate on March 31, 2001 was 126.25 .

From the purely risk management viewpoint, generating ex post profits may not be enough to justify the intervention operation as a smart investment fund management. The relevant question is whether the risk (potential losses) being taken is small or large compared to realized profits. ${ }^{6}$ There are two types of risk, interest rate risk and exchange rate risk. How much risk is associated with the position at the end of March 2001 depends on the volatility of the dollar and yen interest rates and the exchange rate, and correlation between the interest rate differential and the exchange rate. It also depends on how quickly the monetary authorities could liquidate their positions, if necessary, without affecting the market. However, the monetary authorities can be regarded as a long-term investor, where risk tolerance is extremely high, and be able to ride over the cycle. Therefore the risk vs. profits should be measured in the long term, say in the analogy of the equity premium puzzle. In the Account, there are reserves that are set aside for potential losses from the adverse movement of the yen/dollar exchange rate. This can be viewed as reflection of risk management by the authorities.

\section{Timing, Intention and Strategy: first approach}

In order to evaluate whether the intervention worked, it is important to make working assumptions on the counter-factual exchange rate level had the intervention not occurred and on the intention of the monetary authorities.

The intention of the monetary authorities can be classified into the following four categories. When the authorities are aiming at putting a break on the recent trend of the exchange rate movement, that is called the lean-against-the-wind interventions. This type can be further subdivided into an intervention that are intended to reverse the trend and an intervention that are intended only to slow down the speed (smoothing). For example, when the yen has appreciated, the intervention to sell the yen is regarded as the lean-against-the-wind operations. When the trend is reversed (that is, the yen 
depreciated due to intervention), the reversing intervention is regarded as being effective. If the yen did not depreciate, but the rate of appreciation becomes smaller after the intervention than before, then the intervention was effective as a smoothing operation, but not as a reversing operation.

There is another type of intervention. When the yen has depreciated, an intervention of selling yen can be conducted to push the yen further into depreciation. This strategy is commonly called a lean-in-the-wind operation. The intervention goes with the market trend. When the level is considered to be undesirable (say, the yen to overvalued), but the market is on the way to correct the level, a lean-in-the-wind operation is conducted to hasten the return to a normal level. If the authorities intention is to accelerate the recent change in the same direction, the operation is considered successful if the rate of yen depreciation (appreciation) is higher after the yen-selling intervention than before. If the authorities' intention was just to make sure that the direction would continue, then the yen depreciation after the yen-selling intervention is enough to call a success.

In order to make judgment of effectiveness, the yen trend before intervention on day $t$ is defined as the change in the yen/dollar rate (New York close) from t-2 to $t-1$. Then the effect of intervention is contained in the change in the yen/dollar rate (New York close) from t-1 to t. By categorizing the intervention effects measured by these "before" and "after" comparisons produce Table 6 .

\section{Insert Table 6 about here}

Most common type of interventions were lean-against-the-wind interventions when there was yen appreciation. There were 119 of them, and only in about half of the time, it was successful in reversing the trend (that is, appreciation the day before, and depreciation on the day of intervention). (Recalling, Section 3, most of failures come from the period of the first half of 1995, when the yen appreciated from 100 to 80 , despite continuous interventions). However, if the standard for success is relaxed to be less appreciation due to intervention, then, almost $70 \%$ of time, interventions were 
successful.

There were 19 cases of lean-against-the-wind operation in an attempt to stop yen depreciation. Of the 19 interventions, 10 of them reversed the trend, and 17 of them were successful in at least slowing down the yen depreciation.

When the yen was depreciating, there were 49 interventions to sell the yen to depreciate further the yen. These lean-in-the-wind operations were not particularly successful. Out of 49 times, the yen depreciation accelerated only 11 times. More than half of the time, the yen appreciated than depreciated on the day of yen-selling interventions that followed some yen depreciation. This may be counter to a conventional wisdom, it is easier to go with the market rather than against the market.

The lean-in-the-wind interventions in an attempt to appreciate the yen had only 13 cases, but were successful in accelerating the yen appreciation, or at least keeping yen appreciation, in more than $60 \%$ of time.

The tabulation is only suggestive, and not conclusive in evaluating effects of interventions. The table is created from only days when the intervention was conducted. One might think that even without intervention, autonomous market dynamics may correct overshooting. For example, a sharp yen appreciation may be followed by some yen depreciation (correction of overshooting), even without intervention. In order to evaluate effectiveness of intervention, we need to assume some process of the exchange rate movement without intervention. The tabulation above does not give us a good answer on this point. The next section uses a regression analysis using all data, so that the exchange rate movement without intervention is estimated in the regression equation.

\section{Effectiveness of intervention: Regression Approach}

A regression equation for the exchange rate movement is estimated using all daily data in the sample, from April 1991 to March 2001. When there is no intervention, the exchange rate change 
(from $t-1$ to $t$ ) is assumed to be a linear function of the change of day before (from $t-2$ to $t-1$ ) and the deviation of the current exchange rate from a long-run equilibrium rate. Here, knowing that about 125 yen/dollar was the dividing line between yen selling and yen purchasing, 125 yen/dollar is assumed to be a long-run equilibrium rate. $^{7}$

When intervention is conducted on date $\mathrm{t}$, the intervention variable, Int has the intervention amount (in 100 million yen), and 0 otherwise. When the US authorities intervened, the Japanese authorities also intervened. There was no "unilateral" US intervention, although most of Japanese interventions were unilateral. The US intervention variable IntF (in million dollars) is used to capture the impact of joint intervention. (A similar exercise was conducted by Humpage (1999) using the intra-day intervention and exchange rate information for the US interventions.)

Therefore it is When the FED intervened, always with the Japanese authorities, the FED intervention variable takes the intervention amount.

$s_{t}-s_{t-1}=\beta_{0}+\beta_{1}\left(s_{t-1}-s_{t-2}\right)+\beta_{2}\left(s_{t-1}-s_{t-1}^{T}\right)+\beta_{3} \operatorname{Int}_{t}+\beta_{4} \operatorname{IntF}_{t}+\beta_{5} \operatorname{IntI}_{t}+\varepsilon_{t}$

where $\varepsilon_{t}=v_{t} \sqrt{h_{t}}$ with $v_{t} \sim N(0,1), h_{t}=\alpha_{0}+\alpha_{1} \varepsilon_{t-1}^{2}+\alpha_{2} h_{t-1}$ $\mathrm{s}_{\mathrm{t}}: \log$ of spot rate (NY close) of day $\mathrm{t}$.

$\mathrm{s}_{\mathrm{t}}^{\mathrm{T}}: \log$ of long-run equilibrium exchange rate, 125 yen.

Int: the Japanese intervention (in 100 million yen)

IntF : the US intervention (in million dollars)

IntI : the initial intervention (Int: if no intervention in 5 preceding business days; 0 : otherwise) 
Results are shown in Table 7. A hypothesis that the exchange rate movement without interventions is random walk cannot be rejected.

\section{Insert Table 7 about here}

When the intervention by the Japanese authorities are effective, we expect $\beta_{3}<0$. For example, if the yen-purchasing intervention (Int $>0$ ) by the Japanese monetary authorities tends to appreciate the yen $\left(\mathrm{s}_{\mathrm{t}}-\mathrm{s}_{\mathrm{t}-1}<0\right)$, then the negative sign of $\beta_{3}$ should be obtained. It turned out that the Japanese intervention was effective in the entire sample and the $2^{\text {nd }}$ half of the sample. Interventions during and after the Sakakibara regime tended to be effective, while the interventions in the first half were not effective. When the sample period is subdivided, it can be shown that the ineffectiveness comes from the period of $1994-95$ period, when the yen appreciated from 100 yen/dollar to 80 yen/dollar. As it was observed in Section 3, interventions in the first half of 1995 were quite frequent, but were not effective to halt the yen appreciation.

The US interventions (which takes a positive value for yen purchasing) are judged to be effective when $\beta_{4}$ is negative. The total effects of the joint interventions are measured by $\beta_{3}+\beta_{4}$. Since all of the US interventions were joint interventions, the magnitude of $\beta_{4}$ may contain any of the nonlinear effects of the joint interventions. The joint interventions by the Japanese and US authorities were effective in the first and second sub-periods as well as the entire sample. The effectiveness of intervention (the magnitude of $\beta_{3}+\beta_{4}$ ) was much higher in joint intervention than the unilateral intervention by the Japanese authorities.

The coefficient of $\beta_{5}$ shows the effectiveness of the first intervention in more than a week beyond just as one of the interventions. The use of such a variable is found in Humpage (1988). The full impact of the first intervention $\beta_{3}+\beta_{5}$ is statistically significant in the full sample and in the second half of the sample.

In the second half of the sample period, it was estimated that $\beta_{3}=-0.0000009$ and $\beta_{4}=$ 
-0.000051 . The Japanese intervention of 100 billion yen moved $0.1 \%$ of the yen/dollar rate, and the U.S. intervention of 1 billion dollars (100 billion yen at 100 yen/\$) tended to have moved the yen by $5 \%$. The magnitude of the US interventions were much higher.

In sum, interventions were generally effective, except a period when the yen appreciated from 100 to 80 in the first half of 1995. The failure of those interventions in 1994-June 1995 may be due to too strong a force of yen appreciation despite repeated interventions, or due to a not-so-effective style of intervention. The interventions since Sakakibara becoming the Director General tended to be effective. The first intervention in more than a week has a larger impact than subsequent interventions. The Japan-US joint interventions were most powerful.

\section{$\underline{\text { 7. Reaction Function }}$}

In this section, a reaction function of the Japanese monetary authorities in its intervention is estimated. It has been casually observed in earlier sections that the intervention is conducted as a reaction to the exchange rate changes in the short run and the deviation in level from the long-run equilibrium rate. A sudden, big change in the exchange rate tends to trigger intervention. This can be a daily change, or an accumulated change in a longer period, such as in a month. Another factor is the deviation from the long-term equilibrium rate. Recall that the dollar was never purchase when the value of the dollar was higher than 125 yen/dollar, and the dollar was never sold when the yen/dollar rate is below the $125 \mathrm{yen} /$ dollar level. This suggests that intervention being dependent on the deviation from a level, say $125 \mathrm{yen/dollar}$, that the authorities regard appropriate.

The reaction function is specified as follows: The intervention (in amounts of yen) is a function of the change in the yen/dollar rate on day $\mathrm{t}-1$, the change in the yen/dollar rate in the previous 21 (business) days, and the percent deviation of the current (day before) level from 125 yen/dollar. Other factors may be relevant to today's intervention. Intervention may be correlated (once intervened, 
another intervention is likely to occur), and the intervention by the U.S. Federal Reserve may prompt Japanese intervention the day after. In addition, whether there was a unilateral intervention by the Japanese authority or a joint intervention the day before may matter. The dummy variable to those possibilities are introduced. The following is the regression equation.

$$
\begin{aligned}
& \operatorname{Int}_{t}=\beta_{0}+\beta_{1}\left(s_{t-1}-s_{t-2}\right)+\beta_{2}\left(s_{t-1}-s_{t-21}\right)+\beta_{3}\left(s_{t-1}-s_{t-1}^{T}\right)+\beta_{4} \operatorname{Int}_{t-1}+\beta_{5} \operatorname{Int} F_{t-1} \\
& \quad+\beta_{6} d s_{t-1} D\left(\text { Int }_{t} \neq 0\right)_{t-1}+\beta_{7} d s_{t-1} D\left(\operatorname{IntF}_{t} \neq 0\right)_{t-1}+\varepsilon_{t}
\end{aligned}
$$

Estimation is done for the entire sample period, the first half (before Mr. Sakakibara became the Director General), and the second half. Estimated results are shown in Table 8. The findings are as follows.

\section{Insert Table 8 about here}

First, there was a tendency to lean-against-the wind, both in the very short-run (the day before) and in the medium run. A positive coefficient of $\beta_{1}\left(\beta_{2}\right)$ implies that yen depreciation in the day before (cumulative yen depreciation in the preceding 21 business days) tends to prompt an intervention of buying the yen. The lean-against-the-wind tendency is observed in the full sample and both sub-samples (although it was not statistically significant in the first sub-sample). The difference between the two sub-samples in the estimates of $\beta_{1}$ means that interventions were conducted not so much in response to daily movement in the first sub-sample, while the daily change did influence the intervention decision in the second sub-sample.

Second, a positive coefficient of $\beta_{3}$ implies that. the more the yen/dollar exchange rate is deviated from 125 yen/dollar, the more likely did the monetary authorities intervene with a larger amount. This is consistently observed throughout the two sub-samples and full sample. However, the tendency of intervention forcing the exchange rate to revert to the mean was greater in the second sub-sample, as the coefficient was about five times larger in the second sub-sample than in the first 
sub-sample.

Third, the predictability of the model as shown in R2 bar varies over the period. The intervention was more predictable in the first sub-sample, while it was not in the second sub-sample. The excerpt that Mr. Sakakibara explained his intervention strategy is confirmed in the rigorous test. Recall that there were many, continuous interventions in the first sub-sample, especially from 1994 to the first half of 1995.

\section{$\underline{8 \text { Concluding Remarks }}$}

In this paper, effectiveness of the Japanese interventions was examined from various angles. First, the history of the yen/dollar movement and intervention during the 1990s was reviewed. Intervention strategy employed by Sakakibara seemed to be distinctively different from his predecessors, as mentioned in his book. Second, the Japanese interventions during the 1990s produced large profits from realized capital gains, unrealized capital gains and profits from the interest rate differentials. The Japanese monetary authorities were judged as a successful, thus stabilizing, speculator, earning close to 9 trillion yen in ten years. Third, a regression analysis reveals that intervention during the second half of the 1990s in Japan produced intended effects on the yen. The US intervention in the yen/dollar market was more powerful than the Japanese unilateral intervention.

There are more issues that should be examined in relation to interventions. In this paper, the channel of effectiveness was not discussed at all. Effects through signaling are presumed, but not analyzed. Volatility effects are also not analyzed. These are left for future studies. 
References

Dominguez, Kathryn (1990). "Market Responses to Coordinated Central Bank Intervention," Carnegie-Rochester Series on Public Policy, vol. 32, North-Holland: 121-164.

Dominguez, Kathryn and Jeffrey Frankel (1993a). "Does Foreign Exchange Intervention Matter? The Portfolio Effect," American Economic Review, December: 1356-1369.

Dominguez, Kathryn and Jeffrey Frankel (1993b). "Foreign Exchange Intervention: An Empirical Assessment," in J. A. Frankel (ed.) On Exchange Rates, Chapter 16, Cambridge: MIT Press: 327-345.

Dominguez, Kathryn and Jeffrey Frankel (1993c). Does Foreign Exchange Intervention Work?, Washington DC: Institute for International Economics.

Edison, Hali J. (1993). The Effectiveness of Central-Bank Intervention: A Survey of the Literature After 1982, Special Papers in International Economics, no. 18, Princeton, N.J.: Princeton University, July 1993.

Humpage, Owen (1988). "Intervention and Dollar's Decline." Federal Reserve Bank of Cleveland. Economic Review, vol. 24, Qtr. 2: 2-17.

Humpage, Owen (1999). "U.S. Intervention: Assessing the Probability of Success," Journal of Money, Credit, and Banking, vol.31, No.4, November: 731-747.

Sakakibara, Eisuke (2000). The day Japan and the World shuddered: establishment of Cyber-capitalism, Chuo-Koron Shin Sha, April.

Sarno, Lucio and Mark P. Taylor, (2001). "Official Intervention in the Foreign Exchange Market: Is It Effective and, If So, How Does It Work?” Journal of Economic Literature, vol. XXXIX, September: 839-868.

Ramaswamy, Ramana and Hossein Samiei, (2000). "The Yen-Dollar Rate: Have Interventions Mattered?" IMF Working Paper, WP/00/95, International Monetary Fund. 


\begin{tabular}{|l|l|l|l|l|l|}
\hline \multicolumn{6}{|c|}{ Table 1: Comparison of institutional aspects of intervention } \\
\hline Decision & $\begin{array}{l}\text { Ministry } \\
\text { Finance }\end{array}$ & $\begin{array}{l}\text { USA } \\
\text { Treasury (lead) } \\
\text { and FRB }\end{array}$ & $\begin{array}{l}\text { ECB } \\
\text { consultation in } \\
\text { with EcoFin } \\
\text { Concil }\end{array}$ & $\begin{array}{l}\text { H.M. Treasury } \\
\text { and BOE (as } \\
\text { monetary policy) }\end{array}$ \\
\hline Agent & BOJ & New York FED & ECB & BOE \\
\hline Disclosure & $\begin{array}{l}\text { April } \\
\text { 1991-present. (1-3 } \\
\text { month delay). Day, } \\
\text { Amount, Currency }\end{array}$ & $\begin{array}{l}\text { All since 1973? } \\
\text { A-3 month } \\
\text { delay) Not disclosed } \\
\text { Amount, Day, } \\
\text { Time, Currency }\end{array}$ & $\begin{array}{l}\text { Year 2000 to } \\
\text { present. } \\
\text { Day, Amount. }\end{array}$ \\
\hline
\end{tabular}

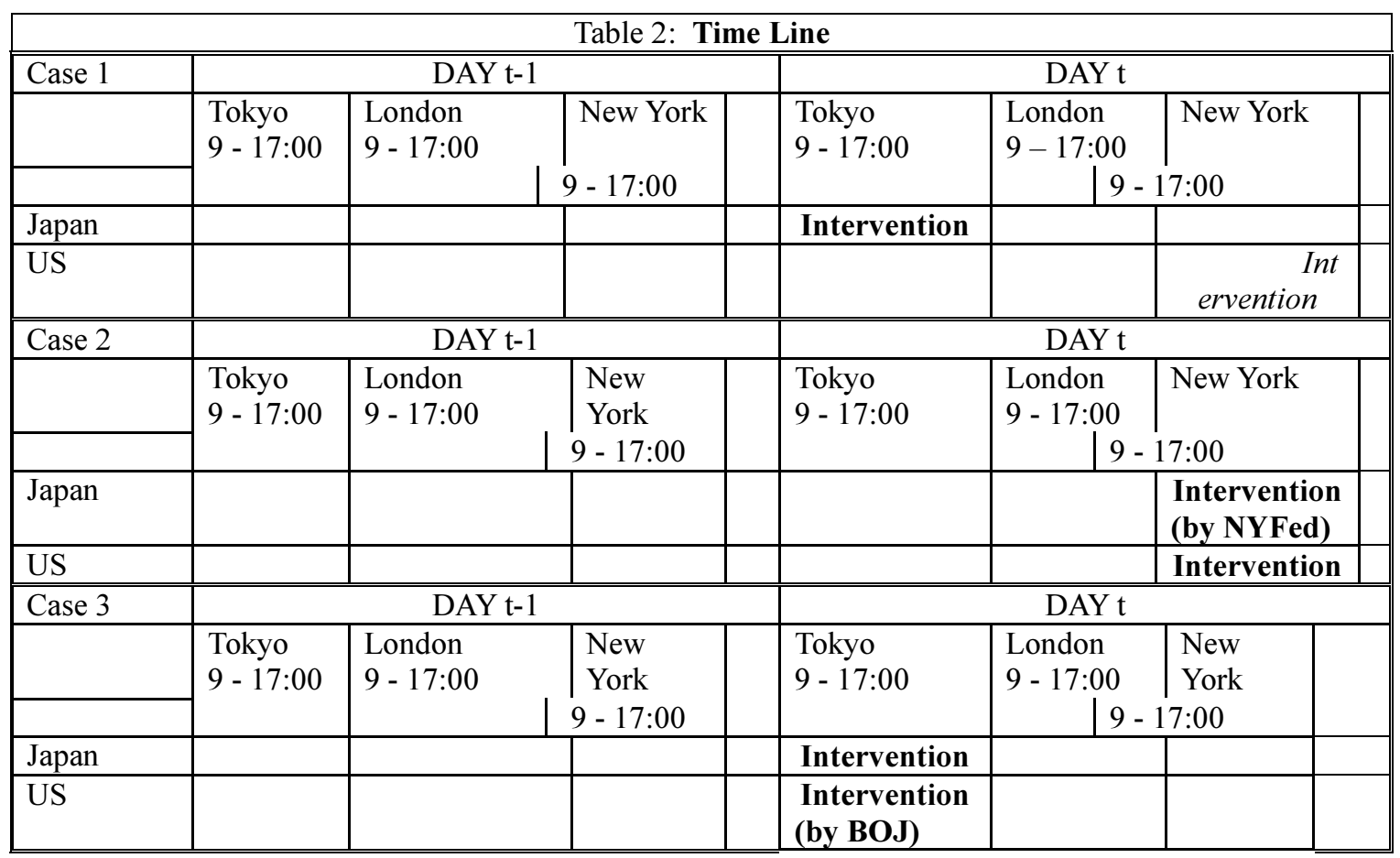




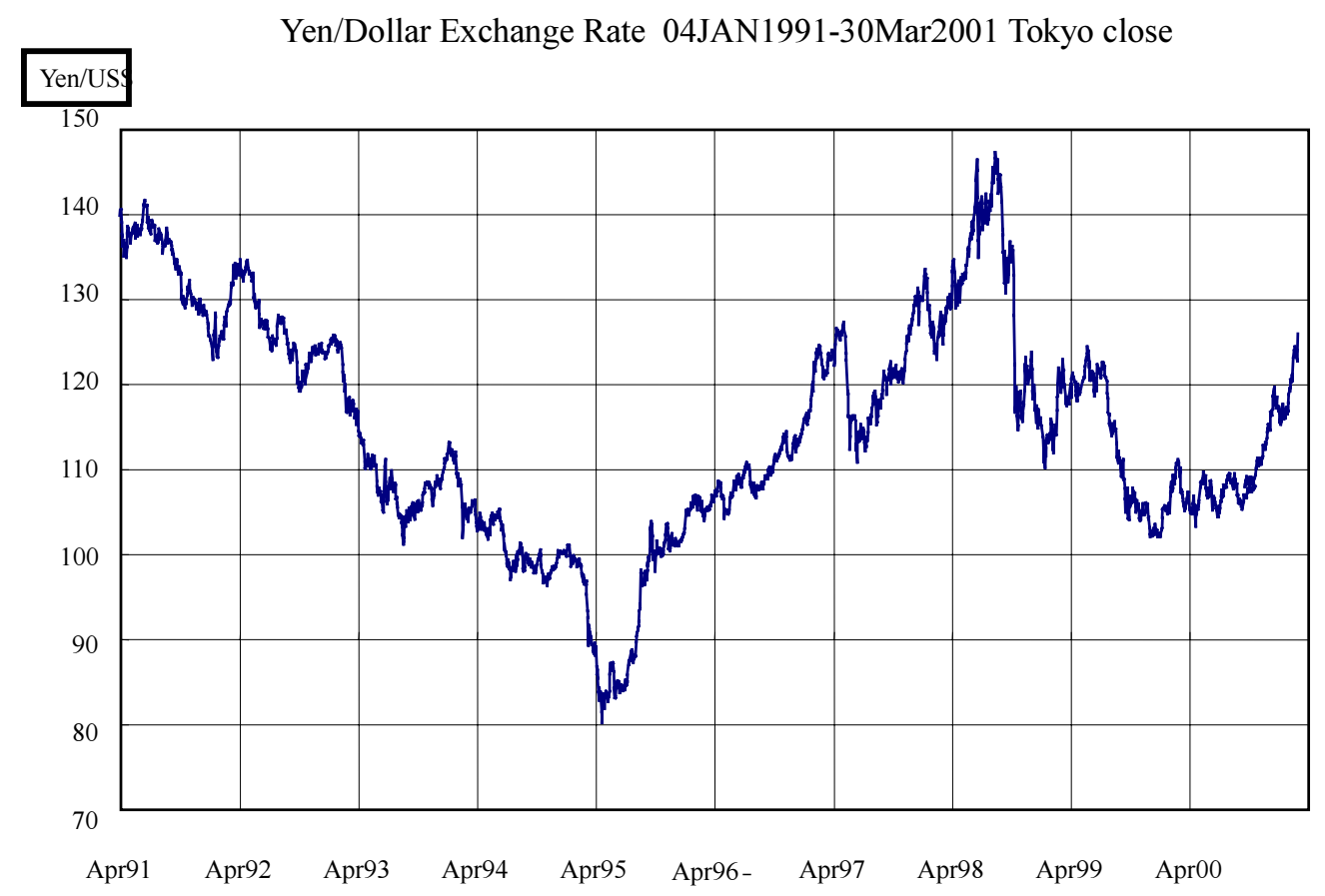

(yen100mil)

Amounts of Intervention (monthly aggregation)

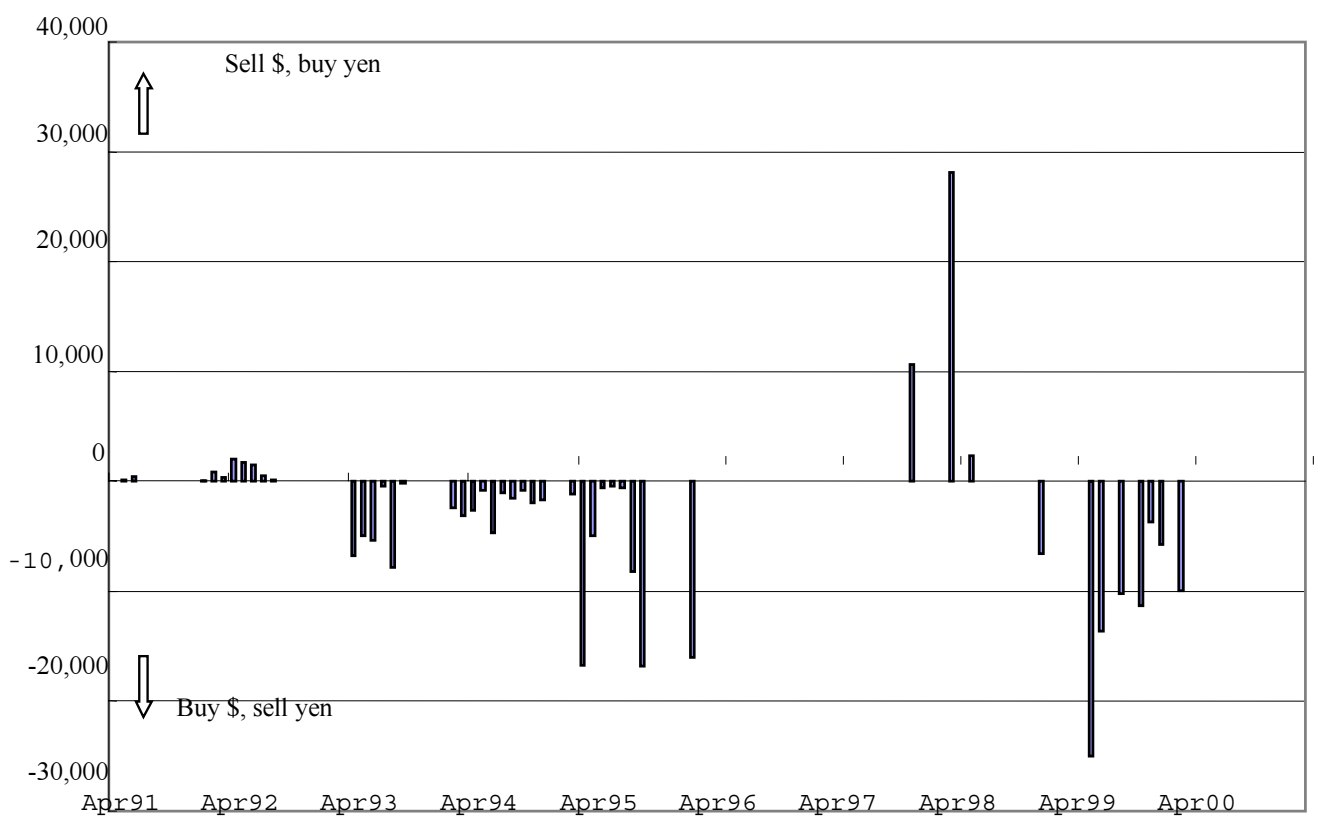

Figure 1 


\begin{tabular}{|c|c|c|c|c|}
\hline \multicolumn{5}{|c|}{ Table 3: Intervention by exchange rate brackets } \\
\hline Rate(central rate) & & & & 100 million yen \\
\hline At or above & Less than & Direction & Number of days & Sum of Amounts \\
\hline 140 & 145 & Sell US\$ & 3 & 2,736 \\
\hline 135 & 140 & Sell US\$ & 1 & 139 \\
\hline 130 & 135 & Sell US\$ & 8 & 30,581 \\
\hline 125 & 130 & Sell US\$ & 20 & 15,338 \\
\hline 120 & 125 & Buy US\$ & 2 & 17,109 \\
\hline 115 & 120 & Buy US\$ & 4 & 21,568 \\
\hline 110 & 115 & Buy US\$ & 17 & 13,815 \\
\hline 105 & 110 & Buy US\$ & 28 & 38,310 \\
\hline 100 & 105 & Buy US\$ & 50 & 63,977 \\
\hline 95 & 100 & Buy US\$ & 35 & 27,257 \\
\hline 90 & 95 & Buy US\$ & 9 & 5,406 \\
\hline 85 & 90 & Buy US\$ & 16 & 20,718 \\
\hline 80 & 85 & Buy US\$ & 7 & 3,680 \\
\hline & & Subtotal, Sell US\$ & 32 & 48,794 \\
\hline & & Subtotal, Buy US\$ & 168 & 211,860 \\
\hline & & Total & 200 & 260,654 \\
\hline \multicolumn{5}{|c|}{$\begin{array}{l}\text { Notes: In addition to these Yen/\$ intervention, } 1 \text { Sell\$/BuyDM, } 1 \text { BuyDM/Sell yen, } 5 \text { Sell } \$ \text { /Buy } \\
\text { Rupiah, } 5 \text { Buy Euro/Sell Yen interventions. }\end{array}$} \\
\hline \multicolumn{3}{|c|}{ Lowest point (Central rate, Tokyo)of Sell US\$ } & \multicolumn{2}{|l|}{126.50} \\
\hline \multicolumn{3}{|c|}{ Highest point (Central rate, Tokyo) of Buy US\$ } & \multicolumn{2}{|l|}{122.65} \\
\hline
\end{tabular}


Table 4 Calculation of Realized and Unrealized gains

\begin{tabular}{|c|c|c|c|c|c|}
\hline & $\begin{array}{l}\text { Intervention } \\
\text { in billion } \\
\text { yen (A) }\end{array}$ & $\begin{array}{l}\text { Intervention } \\
\text { in } \\
\text { US \$ billion } \\
\text { (B) }\end{array}$ & $\begin{array}{l}\text { Average } \\
\text { exchange } \\
\text { rate } \\
(\text { yen } / \$) \\
(\mathrm{C})\end{array}$ & $\begin{array}{l}\text { Realized gains (in } \\
\text { billion yen) of } \\
\text { buying } \$ 37.42371 \text { at } \\
104.17 \text { and selling } \\
\$ \text { at } 130.38\end{array}$ & $\begin{array}{l}\text { Unrealized gains } \\
\text { (in billion yen) of } \\
\text { selling } \\
(203.4-37.4) \\
\text { billion dollars } \\
\text { evaluating at } \\
126.25 \text { yen } \\
\text { against inventory } \\
\text { cost of } 104.17\end{array}$ \\
\hline $\begin{array}{l}\text { Subtotal, } \\
\text { Sell US\$ }\end{array}$ & 4879.4 & 37.42371 & 130.38 & \multirow[t]{2}{*}{981.14} & \multirow[t]{2}{*}{3665.25} \\
\hline $\begin{array}{l}\text { Subtotal, } \\
\text { Buy US\$ }\end{array}$ & 21186.0 & 203. & 104.17 & & \\
\hline Calculation & See Table 3 & Note (1) & $(\mathrm{A}) /(\mathrm{B})$ & $\begin{array}{l}=37.42371^{*} \\
(130.38-104.17)\end{array}$ & $\begin{array}{l}=(21186-4879.4)^{*} \\
(126.25-104.17)\end{array}$ \\
\hline \multicolumn{6}{|c|}{$\begin{array}{l}\text { Notes: (1) For each intervention day, the exchange rate of Tokyo market (central rate) is applied to } \\
\text { calculate the US\$ equivalent. Then all intervention days, separately for sell US\$ and for buy US\$, are } \\
\text { aggregated. } \\
\text { (2) In calculating unrealized gains, the NY close on March } 30,2001 \text { is used. The yen/dollar rate was } \\
126.25 \text { yen/dollar. }\end{array}$} \\
\hline
\end{tabular}


Table 5: Calculation of interest income

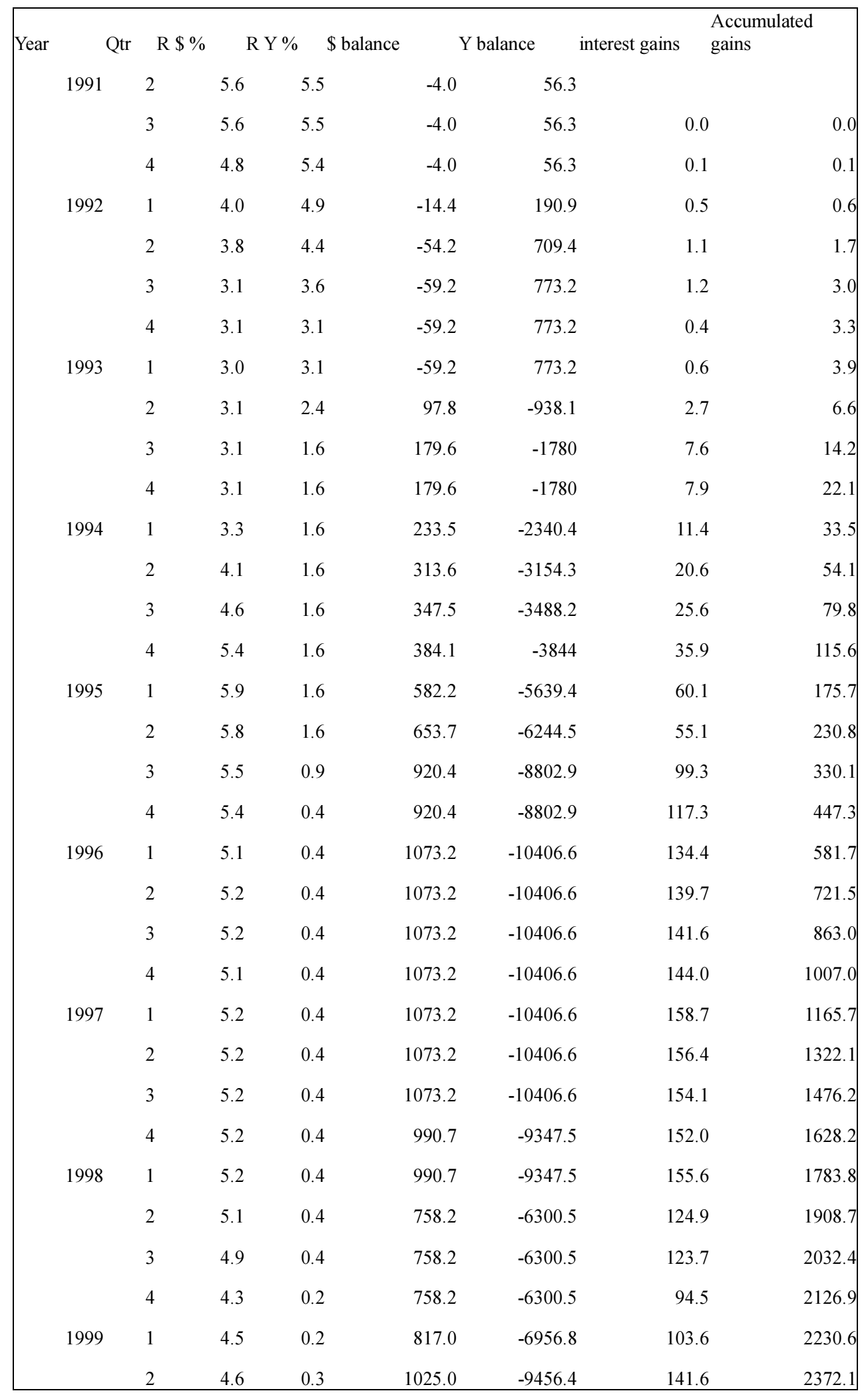




\begin{tabular}{|c|c|c|c|c|c|c|c|}
\hline & 3 & 4.8 & 0.4 & 1231.6 & -11844.0 & 167.0 & 2539.2 \\
\hline & 4 & 5.2 & 0.12 & 1377.6 & -13349.2 & 183.2 & 2722.4 \\
\hline \multirow[t]{4}{*}{2000} & 1 & 5.7 & 0.07 & 1527.6 & -14921.4 & 230.5 & 2952.9 \\
\hline & 2 & 5.9 & 0.05 & 1659.6 & -16306.8 & 258.9 & 3211.8 \\
\hline & 3 & 6.2 & 0.25 & 1659.6 & -16306.8 & 266.5 & 3478.3 \\
\hline & 4 & 6.2 & 0.41 & 1659.6 & -16306.8 & 265.8 & 3744.1 \\
\hline 2001 & 1 & 4.9 & 0.23 & 1659.6 & -16306.8 & 230.7 & 3974.8 \\
\hline
\end{tabular}

Notes: (1) The dollar interest rate is the 3-month Treasury bill yield; (2) The yen interest rate is the 3-month Financial Bill yield; (3) the dollar balance of $t$ is the sum of dollar balance of $t-1$ and the intervention amount (in dollar) in $\mathrm{t}$, and the yen balance is the sum of yen balance of $\mathrm{t}-1$ and the intervention amount (in yen) in $\mathrm{t}$; (4) interest income is the difference of income in dollar, that is dollar balance times dollar interest rate (then converted in yen) and payment in yen, that is yen balance times yen interest rate. The interest rate shown in the table is annualized, so that the calculation should use $1 / 4$ of the rate shown in the table; (5) accumulated gains of $t$ is the sum of accumulated gains of $t-1$ and interest gains of $t$. 
Table 6: Were interventions successful, given Interventions are conducted; April 1991-March 2001;

\begin{tabular}{|c|c|c|c|c|c|c|}
\hline Direction & $\begin{array}{l}\text { BEFORE } \\
\mathrm{s}(\mathrm{t}-1)-\mathrm{s}(\mathrm{t}-2)\end{array}$ & $\begin{array}{l}\text { Number of } \\
\text { interventions }\end{array}$ & $\begin{array}{l}\text { AFTER } \\
s(t)-s(t-1)\end{array}$ & $\begin{array}{l}\text { Benchmark } \\
\text { (If no } \\
\text { intervention) }\end{array}$ & $\begin{array}{l}\text { Number of } \\
\text { success }\end{array}$ & $\begin{array}{l}\text { Rate of } \\
\text { success }\end{array}$ \\
\hline \multirow[t]{2}{*}{ Buy yen } & \multirow[t]{2}{*}{$\begin{array}{l}\text { Yen Depreciation } \\
\text { (lean-against) }\end{array}$} & \multirow[t]{2}{*}{19} & $\begin{array}{l}\text { Appreciation? } \\
\text { (Reversal) }\end{array}$ & $\begin{array}{l}\text { Random } \\
\text { Walk }\end{array}$ & 10 & $52.6 \%$ \\
\hline & & & $\begin{array}{l}\text { Slower? } \\
\text { (Smoothing) }\end{array}$ & & 17 & $89.5 \%$ \\
\hline \multirow[t]{2}{*}{ Buy yen } & \multirow[t]{2}{*}{$\begin{array}{l}\text { Yen Appreciation } \\
\text { (lean-in) }\end{array}$} & \multirow[t]{2}{*}{13} & $\begin{array}{l}\text { Accelerating? } \\
\text { (Push the trend) }\end{array}$ & & 8 & $61.5 \%$ \\
\hline & & & $\begin{array}{l}\text { Not depreciation } \\
\text { (Appreciation) }\end{array}$ & $\begin{array}{l}\text { Random } \\
\text { Walk }\end{array}$ & 8 & $61.5 \%$ \\
\hline \multirow[t]{2}{*}{ Sell yen } & \multirow[t]{2}{*}{$\begin{array}{l}\text { Yen Appreciation } \\
\text { (lean-against) }\end{array}$} & \multirow[t]{2}{*}{119} & $\begin{array}{l}\text { Depreciation? } \\
\text { (Reversal) }\end{array}$ & $\begin{array}{l}\text { Random } \\
\text { Walk }\end{array}$ & 54 & $45.4 \%$ \\
\hline & & & $\begin{array}{l}\text { Slower? } \\
\text { (Smoothing) }\end{array}$ & & 83 & $69.7 \%$ \\
\hline \multirow[t]{2}{*}{ Sell yen } & \multirow[t]{2}{*}{$\begin{array}{l}\text { Yen Depreciation } \\
\text { (lean-in) }\end{array}$} & \multirow[t]{2}{*}{49} & $\begin{array}{l}\text { Accelerating? } \\
\text { (Push the trend) }\end{array}$ & & 11 & $22.4 \%$ \\
\hline & & & $\begin{array}{l}\text { Not appreciation } \\
\text { (Depreciation) }\end{array}$ & $\begin{array}{l}\text { Random } \\
\text { Walk }\end{array}$ & 19 & $38.8 \%$ \\
\hline
\end{tabular}


Table 7: Effectiveness of intervention

$s_{t}-s_{t-1}=\beta_{0}+\beta_{1}\left(s_{t-1}-s_{t-2}\right)+\beta_{2}\left(s_{t-1}-s_{t-1}^{T}\right)+\beta_{3} \operatorname{Int}_{t}+\beta_{4} \operatorname{IntF}_{t}+\beta_{5} \operatorname{IntI}_{t}+\varepsilon_{t}$

where $\varepsilon_{t}=v_{t} \sqrt{h_{t}}$ with $v_{t} \sim N(0,1), h_{t}=\alpha_{0}+\alpha_{1} \varepsilon_{t-1}^{2}+\alpha_{2} h_{t-1}$

$\mathrm{s}_{\mathrm{t}}$ : spot rate (NY close) of day $\mathrm{t}$.

$\mathrm{s}^{\mathrm{T}}{ }_{\mathrm{t}}$ : long-run equilibrium exchange rate, 125 yen.

Int: Japanese intervention amount

IntF : FED intervention amount

IntI : Initial intervention ( $=$ Int, if no intervention in 5 preceding business days; $=0$, otherwise)

\begin{tabular}{cccc}
\hline & FULL sample: & First half: & Second Half \\
& 01Apr91-30Mar01 & 01Apr91-20Jun95 & 21Jun95-30Mar01 \\
\hline$\beta 0$ & 0.0001 & -0.0004 & 0.0003 \\
$\beta 1$ & $(0.0002)$ & $(0.0002)^{\dagger}$ & $(0.0003)$ \\
$\beta 2$ & -0.015 & -0.038 & -0.023 \\
& $(0.02)$ & $(0.036)$ & $(0.031)$ \\
$\beta 3$ & -0.001 & -0.0019 & -0.00065 \\
& $(0.001)$ & $(0.0016)$ & $(0.002)$ \\
$\beta 4$ & -0.0000006 & 0.0000037 & -0.0000009 \\
& $(0.0000002)^{* *}$ & $(0.000001)^{* *}$ & $(0.0000002)^{* *}$ \\
$\beta 5$ & -0.0000138 & -0.000011 & -0.000051 \\
& $(0.000003)^{* *}$ & $(0.000004)^{* *}$ & $(0.000000)^{* *}$ \\
$\alpha 0$ & -0.0000017 & 0.000001 & -0.0000012 \\
& $(0.0000004)^{* *}$ & $(0.000003)$ & $(0.0000004)^{* *}$ \\
$\alpha 1$ & 0.000003 & 0.000006 & 0.000005 \\
& $(0.0000008)^{* *}$ & $(0.000003)^{* *}$ & $(0.000002)^{* *}$ \\
$\alpha 2$ & 0.10 & 0.10 & 0.12 \\
& $(0.01)^{* *}$ & $(0.02)^{* *}$ & $(0.03)^{* *}$ \\
R2 Bar & 0.84 & 0.75 & 0.78 \\
OBS & $(0.03)^{* *}$ & $(0.07)^{* *}$ & $(0.05)^{* *}$ \\
\hline
\end{tabular}

Note: Standard errors are given in parentheses.

$\uparrow$ Statistically significant at the 10-percent level.

*Statistically significant at the 5-percent level.

**Statistically significant at the 1-percent level.

$\mathrm{Q}(10)$ tests suggest no serial correlation. 
Table 8. Reaction Function

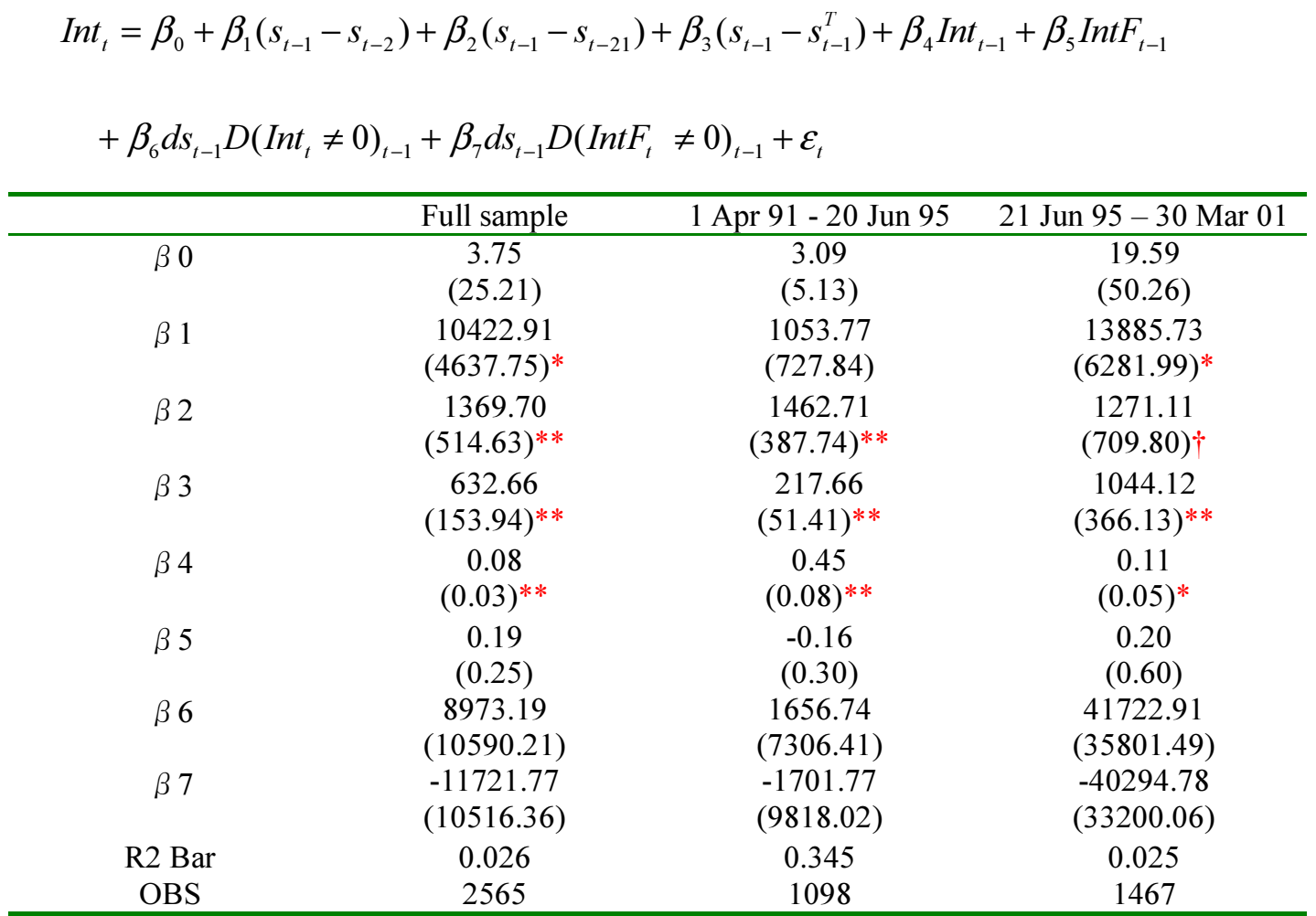

Note: Standard errors are given in parentheses. Q(10) Test is rejected. Estimated by GMM.

$\dagger$ Statistically significant at the 10-percent level.

*Statistically significant at the 5-percent level.

**Statistically significant at the 1-percent level.

$\beta 1>0, \beta 2>0$ : Lean against the wind.

$\beta 3>0$, further the rate is away from 125 yen, more likely to have a larger intervention.

$\beta 4>0$, there is a tendency to have subsequent interventions. 
Notes:

\footnotetext{
${ }^{1}$ However, data were not released so that any academic follow up studies were not possible.

${ }^{2}$ Some other technical details may be interest to those who do micro-structure research of the foreign exchange marekt: the distinction between intervention carried out by the Bank of Japan and that carried out by other central banks on behalf of the Bank of Japan; and whether it was carried out through interbank transactions or through voice/electronic brokers.
}

${ }^{3}$ The names of the Bureau and the Division were changed to the International Bureau and the Foreign Exchange Markets Division, in January 2001 and June 2001, respectively.

${ }^{4}$ However, timing of financial bill issues can be sufficiently distanced in time from intervention. If the interest rate is targeted by the Bank of Japan monetary policy, financial bill issues will be matched by open market purchase of short-term securities by the Bank of Japan, and later when intervention, selling the yen and purchasing the dollar, is conducted, additional yen in the market is absorbed by sterilizing operations of the Bank of Japan. In this sense, "automatic" interventions may not be literally correct.

${ }^{5}$ Financial turmoil hit the international capital markets in the preceding few months. In August 1995, the Russian government de facto defaulted on its government bonds. This sent a shock wave to the bond market, and various risk spreads widened. Long-term Capital Management, a hedge fund which had large positions betting on shrinking spread, went under in September. Other hedge funds and leveraged institutions started to unwind their leveraged positions. Many had borrowed in yen and invested in various assets. The unwinding of yen carry caused the sudden change.

${ }^{6}$ Kelly Eckhold, Reserve Bank of New Zealand, pointed out the risk associated with exchange rate volatility to me.

${ }^{7}$ For robustness check, an alternative of long moving average could be used, but major results would not change. 